\title{
ASSIMILATION OF IMMIGRANTS IN SPAIN: A LONGIUUDINAL ANALYSIS
}

Mario zzquierdo, Aitor Lacuesta. and Raquet tegas

Documentos de Trabajo. N. 0904

\section{BANCOTESPANA}


ASSIMILATION OF IMMIGRANTS IN SPAIN: A LONGITUDINAL ANALYSIS 
ASSIMILATION OF IMMIGRANTS IN SPAIN: A LONGITUDINAL

ANALYSIS ${ }^{*}$

Mario Izquierdo and Aitor Lacuesta ${ }^{(*)}$

BANCO DE ESPAÑA

Raquel Vegas

FEDEA

\footnotetext{
$\left({ }^{\star}\right)$ The authors would like to thank the contribution of the participants at seminars and conferences at Banco de España, INSIDE, EALE, Simposio de Análisis Económico and ECB/CEPR Labour Market Workshop. We are in debt with the National Institute of Statistics that provided the data on non-renewals and the Social Security that provided the Muestra Continua de Vidas Laborales (MCVL) and kindly solved all our questions, especially Almudena Durán. Raquel Vegas was working at Banco de España while most of this research project was carried-out. The opinions and views expressed in this paper do not necessarily reflect those of the Banco de España.

$\left.{ }^{(\star}\right)$ Corresponding author: Aitor Lacuesta. DG Economics, Statistics and Research, Banco de España, C/ Alcalá 48, 28014 Madrid, Spain. E-mail: aitor.lacuesta@bde.es.
} 
The Working Paper Series seeks to disseminate original research in economics and finance. All papers have been anonymously refereed. By publishing these papers, the Banco de España aims to contribute to economic analysis and, in particular, to knowledge of the Spanish economy and its international environment.

The opinions and analyses in the Working Paper Series are the responsibility of the authors and, therefore, do not necessarily coincide with those of the Banco de España or the Eurosystem.

The Banco de España disseminates its main reports and most of its publications via the INTERNET at the following website: http://www.bde.es.

Reproduction for educational and non-commercial purposes is permitted provided that the source is acknowledged.

\section{(C) BANCO DE ESPAÑA, Madrid, 2009}

ISSN: 0213-2710 (print)

ISSN: 1579-8666 (on line)

Depósito legal: M. 14475-2009

Unidad de Publicaciones, Banco de España 


\begin{abstract}
In this paper we use the Continuous Sample of Working Histories 2005 (MCVL2005) to analyze the earnings assimilation of migrants from outside the EU-15 in Spain. Using our panel dataset we show that immigrants reduce around the half of the initial wage gap respect to natives the first 5 to 6 years after arrival. However, no further reductions of the remaining wage gap are estimated. We also show that results based on cross-section data are downward biased since an important increase in the quality of migrants has taken place over the recent years. This skill upgrading of new immigrant cohorts is evident in the Spanish case as well as the depreciation of the value of most of the experience that is brought from abroad. We can associate the improvement in the skill of immigrants to a change in the composition of new entrants. An important mechanism underlying the assimilation is the higher likelihood of recent immigrants in changing jobs among different sectors and firms, but also improving their situation within the same firm. Finally, some caveats should be taken into account when interpreting our results given that immigration phenomenon is quite recent in the Spanish labour market and it has taken place in an especially positive economic environment.
\end{abstract}

Keywords: Immigration, assimilation, longitudinal data, selection, human capital.

Clasificación JEL: J31, J61. 
Assimilation of immigrants in the host country is a broad concept. Some people emphasize the fact that immigrants adopt the values, culture and traditions with the underlying idea of keeping a cohesive society. However, that concept of assimilation is certainly difficult to measure. A much easier concept to quantify is assimilation in earnings. It has been proven that immigrants have a negative wage gap respect to observationally equivalent natives. This gap partly reflects the fact that migrants cannot use all the human capital they have acquired in their country of origin. In that case, a typical human capital model [Sjaastad (1962), Ben Porath (1967)] would predict a large incentive to invest in human capital upon arrival which will consequently generate a steeper wage earnings profile along the migrants' life cycle compared to otherwise identical native workers. One of the most important investments once in a new country is the language, but there are other issues to be learnt, from particular regulations to country-specific skills. Moreover, in a regulated labour market such as the Spanish one, there are many institutions that can contribute to non-market clearing wage differentials across regions or sectors [Izquierdo and Lacuesta (2005)]. Migrants are more prone to benefit from those differences since they have lower social attachments than natives. Therefore, the initial wage gap between migrants and non-migrants might disappear as long as migrants reallocate themselves into jobs that offer better economic opportunities.

The literature on assimilation of wage earnings starts with Chiswick (1978) who found an assimilation rate of $2 \%$ per year in the United States. This means that an initial wage gap of $30 \%$ is completely vanished after 15 years of residence. However, the robustness of his empirical results was criticized because of the usage of a single cross section since with this type of data migrants with different labour market experience in the destination country belonged to different entry cohorts. If there is a decrease in the quality of migrants that entered the country over time, as it happened in the United States [Borjas (1999)], the wage growth estimated is an upward biased measure of the real one. On the other hand, if there is an improvement in the quality of immigrants, the actual wage growth would be underestimated. This problem was traditionally solved by using repeated cross sections and following the history of different individuals belonging to the same entry cohort [LaLonde and Topel (1992)].

Even in the case that the quality of migrants does not change over different entry cohorts, we might get biased estimations of the actual assimilation derived from selective emigration. Let's assume that migrants who decide to go back home after a while are those who perform the worse. In that case, following the wage growth of a particular entry cohort gets an upward biased estimation of the actual wage growth because those foreigners that have stayed longer are better than the average foreigner at the moment of entry. We might partly solve this problem by using longitudinal data as in Wei-Yin $\mathrm{Hu}$ (2000) and Lubotsky (2007). Longitudinal data tracks the wage growth of individuals who belonged to a particular entry cohort and stayed for a certain number of years in the country. In a sense, with longitudinal data we empirically estimate the assimilation profile of that selective group of foreigners ${ }^{1}$.

1. Notice that this is not an estimation of the assimilation profile of all foreigners who entered in a particular year. In order to extrapolate the abovementioned results we would require more assumptions. For example, assuming that differences between migrants who succeed and fail are wage level instead of wage growth differences. 
Following the spirit of those papers, we carry-out the first analysis of the earnings assimilation profile of immigrants in Spain using a longitudinal dataset (Continuous Sample of Working Histories 2005). The Spanish case is particularly interesting to analyze. By one hand, immigration phenomena has been especially intense over the last decade, since the annual inflow of immigrants, on average more than 500.000 since 2000 , pushed up the percentage of immigrants in the Spanish population from $2 \%$ in 2000 to $11 \%$ six years later. Over this period, immigration accounted for more than $80 \%$ of the total growth in the working age population and almost $50 \%$ of the growth in employment. This immigration shock took place in an especially good economic context, GDP growth was quite robust (3.6\% on average for the period 2000-2006) and unemployment decreased dramatically. In the other hand, the wage assimilation process in a regulated labour market, like the Spanish one, may be quite different than the one observed in more flexible labour markets (US, for example). Labour market institutions, such as the collective bargaining mechanism or employment protection, which configure a quite rigid labour market may play a relevant role. Indeed, in this particular context we might expect a relatively low level of earnings assimilation of immigrants according to other international findings. Antecol et al. (2006) found a relatively low level of earnings assimilation in Australia compared to the United States and Canada and high employment rate assimilation.

In addition, empirical evidence about the behaviour of immigrants in the Spanish labour market is relatively scarce. We know, for instance, that immigrants do not perform very well respect to natives. For instance, Adsera and Chiswick (2007) and Amuedo-Dorantes and de la Rica (2007a) show that immigrants coming from outside the EU-15 tend to earn 30\% less than natives and face a higher unemployment rate (12.3 respect to 7\% among natives in 2007). With respect to assimilation, Amuedo Dorantes and De la Rica (2007a) used a single cross section for 2002 and taking some assumptions due to their data limitations, found that immigrants decreased the wage gap in 15 pp during the first 5 years of residence in Spain. Fernández and Ortega (2006) used the Labour Force Survey data to analyze assimilation in working conditions. Their results failed to find an improvement in their labour conditions, especially in terms of stability in the job.

On the impact of immigration on the functioning of the Spanish labour market, several studies have tried to analyze the impact of the immigration shock on the labour market performance of native workers, mainly in terms of employment. Carrasco et al. (2008) or Amuedo-Dorantes and de la Rica (2007b) tend to find very mild effects on native employment opportunities. With respect to the evolution of productivity, the negative wage gap is associated with a productivity gap and thus, immigration has been called to explain, at least partially, the poor performance of labour productivity over the most recent period [see Banco de España (2006) and Lacuesta et al. (2008)]. On this topic, the analysis of immigrants assimilation will give us some valuable information about the likelihood of a productivity recovery over the near future since if, as in other countries, we observe an assimilation process of immigrants in Spain associated with the acquirement of country-specific skills, this will have a positive impact on productivity evolution over the next years.

The rest of the paper is organized as follows. Next section briefly describes the database we use for the analysis and in the third section we explain the empirical specification of wage equations used to estimate the assimilation process. Fourth section includes main results of the paper about the estimation of these equations while in the fifth section we provide some additional information about the relevance in Spain of changes in the quality 
of different cohorts of immigrants. In the sixth section we try to provide some explanation of the mechanisms that could be behind the process of earning assimilation and, finally, section 7 concludes. 
The data we use comes from the 2005 wave of Continuous Sample of Working Histories ("Muestra continua de Vidas Laborales"). This dataset is formed by a $4 \%$ random sample of all individuals who have had an affiliation in the Social Security during the current year.2 The dataset gives historical information of all relationships within the Social Security System (in terms of employment, unemployment benefits and other contributed pensions perceived) with information about job characteristics such as type of contract, length, sector of activity, working time, and monthly capped earnings joint with some personal information about the worker (sex, age and nationality). The matching of this dataset with data from the Municipal Register of Inhabitants (Padrón Municipal de Habitantes) adds information on education, place of birth, place of residence and some characteristics of the household.

This dataset provides a representative sample of the Spanish labour market. If we compare aggregate figures with Labour Force survey, which is the main source for employment figures in Spain, we basically observe that our dataset offers an appropriate picture of the formal sector of the Spanish labour market In particular, figures coming from MCVL2005 tend to estimate a slightly lower employment level across different age/sex/nationality breakdowns that we could explain by the relevance of the informal sector in the Spanish economy3. This is shown in Ramos Muñoz (2007) where a detailed comparison is carried-out. This study identified most of the differences between the two data sets for youth, females and foreigners. They attribute those differences, as it was mentioned before, to the informal sector. They also analyzed differences in professional status (employee or self-employed), type of contract (temporary versus permanent) and length of the working day; obtaining very similar distributions in both samples. Thus, although we are quite confident about the representativeness of our sample to study the Spanish labour market when we interpret our results we should be aware that we are estimating the assimilation of legal migrants working in the formal sector of the economy. Finally, it is important to note that the information is only representative of the social security records in the current year. Workers in 2005 are a random sample of workers affiliated to the Social Security in 2005, however; for previous years we only observe the historical relationships for those individuals who either work or earn unemployment benefits in 2005. Therefore, workers in years before 2005 are not a representative sample of workers in that particular year because of non-random exit form the labour market ${ }^{4}$. For the purpose of this study, this feature is going to be valuable as it will be noted in the next section.

With respect to the characteristics or our sample, we restrict the sample to males between 25 and 54 years old in order to have the analysis free of selection on the labour market. At those ages, almost all natives and immigrant males are active and this is important since we do not model a participation decision in our framework. We perform the analysis using two different measures of daily wages. Firstly, daily wages are computed as the ratio

2. Indeed, we use information from the simple 2005B that has information on the Social Security records and the Population registers (Padrón) but it does not have any information on fiscal registers. The sample has 1.142.118 individuals.

3. There are some workers from the Public Sector that do not need to be registered in the Social Security and they are registered in what is called clases pasivas o MUFACE. Nowadays the amount that those workers represent is very small.

4. In the future, it is expected to follow up the cohorts adding some information to keep the representativeness of the sample in each particular year. 
between monthly earnings and the days worked in a particular month. Since the data on Social Security contributions is given monthly, this is the more sensible way to proceed. However, since migrants are expected to rotate between employment and unemployment much more than natives, we might be capturing a self selected sample of immigrants (only those who are employed in a particular month). Moreover, we identify some individuals whose firms do contribute to the social security with a certain delay ${ }^{5}$. In order to solve those problems we check the robustness of the results computing daily earnings as the ratio between the sum of the current year earnings and the days worked during the year.

Since there is no earnings information before 1979 we keep individuals who start their labour career after that date. Moreover, we keep track of earnings only in the case of being employed in the Social Security General Regime. We do not take into account earnings obtained as self-employed since they might have more freedom to choose their reported contribution bases and, given this fact, the wage might be a downward proxy of the real earnings. We also drop unemployment insurance earnings. Sometimes, the administrative records report a zero or negative earnings while the person has a contract. Most of the time, this fact means a delay in the payment of social security contributions or adjustments of the administration. The measure of wages using annual earnings should be free of this problem. Many individuals have different contracts during a month, therefore we add up all earnings for an individual in that month. If the total earnings, once all contracts are added up, exceed the corresponding cap per year and group of contribution, we substitute that number for the cap. In order to compute the days worked during a month or a year we consider all contracts in a particular month/year for each individual.

Regarding the definition of a migrant, we use nationality instead of the country of origin to define an individual as a migrant. This is coherent with definitions used in other studies and country of origin is not available for the whole sample of individuals. However, this definition has a potential shortcoming give that a migrant who entered in Spain in the 1980s but got Spanish nationality is observed as a Spanish worker in our sample 6 . Notwithstanding, we think this is not very relevant ${ }^{7}$, at least for the migrants arrived in the last decade since they still have not had enough time to get Spanish nationality. Finally, we restrict the sample of migrants in the empirical exercise to be not members of the EU-15 since immigration from those countries has been traditionally very different to the immigration coming from the rest of the world (with a high share of retirees).

Experience in the Spanish labour market is computed sequentially from the moment the worker enters the sample. If the person entered for the first time the job market in February 1980 we keep that particular monthly earning as his initial earning. The earnings on February 1981 represent the earnings after 1 year of experience and so on ${ }^{8}$. If the person did not work at all in one particular month, he will have a missing value in earnings (or out of the labour force). However, that year counts for the experience profile of the person. Indeed, if the individual comes back to work 5 years after, he is considered to have 5 years more of

5. We treat those as missing values in the monthly payments.

6. We cannot observe those who have double nationatility from the beginning. They will be treated as Spaniards in our sample. According to the labour force survey in the fourth quarter of 2008 there were 88.000 males between 25 and 54 years old represent the $0.8 \%$ of the population.

7. Results do not change by using place of birth on the sample we have availability of this variable.

8. The same reasoning is applied for the second measure of daily wages using current years, but at this point all earnings in a current year should be added up. 
experience. Therefore, experience should be considered as years after the first entry in the labour market ${ }^{9}$.

Many migrants entered Spain with some experience from abroad. However, we do not have information on that issue. This ingredient is crucial in order to compare the wage experience profile of migrants and non-migrants since otherwise, at the moment of entry, we are comparing people at different stages of their working careers. In order to have information on experience abroad we estimate potential experience abroad substracting potential age of entry in the labour market in the origin country to the age of entry in Spain. Potential age of entry in the origin country is 16 if the person has lower education than a university degree and 22 if the person received a university degree. On the other hand the age of entry in Spain is the age of the person at the moment of the first contribution in the social security. One evident problem with this estimation of potential experience is that our measure of education comes from Padrón and as it was commented above it does not appropriately depict actual education, and is not available for every one ${ }^{10}$. Many people present a lower education in the Padrón compared to their real level. This is the case because the administrative data is not updated unless someone changes residence into a different municipality. This problem should be smaller for immigrants since most of them arrive in Spain to work. Even in that case, people might decide not to update the information, since could be inconvenient ${ }^{11}$. However, we are going to assume that answers of foreigners are correct in average.

An additional problem is that the age of entry does not necessarily depict the real age of entry into Spain, since many migrants, as it will be shown later, enter illegally into the country or work in the informal sector even being legal. Lubotsky (2007), who have alternative measures for the age of entry, showed that different measures affect slightly the quantitative results without affecting them qualitatively. Since we do not have alternative measures we need to stick to the abovementioned concept of year of entry. On this regard, the existence of several regularization processes in Spain is problematic. For an illegal migrant that is legalized, years since migration is an upward biased measure of the real years spent in Spain and the number of years abroad is a downward measure of the experience in the home country. Table 1 shows the processes of regularization in the recent past [OECD (2007)]. In order to analyze whether our results are affected by those regularizations, we repeat all the analysis dropping from our sample all individuals who report to have had their first labour experience in those particular years.

9. Since the study is restricted to males between 25 and 54 years old we do not think that exit and re-entry is an important issue.

10. We consider as low educated those who do not report education.

11. Being elected as a member of a public jury depends on the educational attainment. 
Table 1. Regularization processes in the Spanish Economy

\begin{tabular}{|c|c|c|c|c|}
\hline Year & $\begin{array}{l}\text { Number } \\
\text { regularized }\end{array}$ & $\begin{array}{l}\text { Primary policy } \\
\text { target }\end{array}$ & Benefit granted & Conditions \\
\hline 1985-1986 & 38,181 & All foreigners & $\begin{array}{l}\text { Residence and work } \\
\text { permit }\end{array}$ & $\begin{array}{l}\text { Applied to unauthorized workers } \\
\text { and residents. }\end{array}$ \\
\hline 1991 & 110,100 & Workers & $\begin{array}{l}\text { Residence and work } \\
\text { permit }\end{array}$ & $\begin{array}{l}\text { Illegal aliens working in Spain } \\
\text { since May 15, 1991, rejected } \\
\text { asylum seekers or those } \\
\text { with asylum request pending. }\end{array}$ \\
\hline 1996 & 21,300 & $\begin{array}{l}\text { All foreigners }(13,800 \\
\text { work permits and } \\
7,500 \text { residence) }\end{array}$ & $\begin{array}{l}\text { One year residence and } \\
\text { work permit }\end{array}$ & $\begin{array}{l}\text { Applied to those residing in Spain } \\
\text { since January } 1,1996 .\end{array}$ \\
\hline 2000 & 163,900 & All foreigners & $\begin{array}{l}\text { One year residence and } \\
\text { work permit }\end{array}$ & $\begin{array}{l}\text { Applied to those who had } \\
\text { previously held or applied for } \\
\text { either work of residence permits } \\
\text { in the three years prior to } 2000 \text {, } \\
\text { or had filed an asylum application } \\
\text { before } 2000 \text {. }\end{array}$ \\
\hline 2001 & 216,400 & Workers & $\begin{array}{l}\text { One year residence and } \\
\text { work permit }\end{array}$ & $\begin{array}{l}\text { Applied to those who could prove } \\
\text { employment as well as social ties } \\
\text { in Spain. }\end{array}$ \\
\hline 2005 & 548,700 & All foreigners & $\begin{array}{l}\text { Six months residence } \\
\text { and work permit }\end{array}$ & $\begin{array}{l}\text { Applied to those who have an } \\
\text { employment offer lasting for } 6 \\
\text { months. }\end{array}$ \\
\hline
\end{tabular}


Let's start with a model for natives and immigrants wages. Spanish worker enter into the labour market with some specific skills, depending on their gender, education and birth cohort. From that moment on, the wage is increased by a function $\delta^{n}{ }_{k}$ due to a process of on the job learning. Macroeconomic shocks $\mu_{t}$ and an idiosyncratic shock $\varepsilon_{i t}$ affect someone's wage. Given these ingredients, the wage profile of individual i across time (t) is defined as:

$$
\begin{aligned}
& W^{n}{ }_{i t}=e^{\left(\mu_{t}+\varepsilon_{i t}\right)} W^{n}{ }_{0} \prod_{k=1}^{t}\left(1+\delta^{n}{ }_{k}\right) \\
& \ln W^{n}{ }_{i t}=\ln W_{0}^{n}+\sum_{k=1}^{t} \delta_{k}^{n}=f^{n}(\text { educ, birth_cohort })+\sum_{k=1}^{t} \delta^{n}{ }_{k}+\mu_{t}+\varepsilon_{i t}
\end{aligned}
$$

On the other hand, immigrants arrive to the country with certain labour market experience in addition to their initial particular skills. The experience acquired abroad has certain value in the Spanish labour market say $\lambda^{I}$. And once in the country, immigrants start to increase their human capital at a rate $\delta^{I}{ }_{k}$. Given that the individual enters at the age of $t^{2}$, the wage is given by:

$$
\begin{aligned}
& W^{I}{ }_{i t}=e^{\left(\mu_{t}+\varepsilon_{i t}\right)} W^{I}{ }_{0} \prod_{k=1}^{t^{a}}\left(1+\lambda^{I}{ }_{k}\right) \prod_{s=t^{a}}^{t}\left(1+\delta^{I}{ }_{s}\right) \\
& \ln W^{I}{ }_{i t}=\ln W^{I}{ }_{0}+\sum_{k=1}^{t^{a}} \lambda^{I}{ }_{k}+\sum_{s=t^{a}}^{t} \delta^{I}{ }_{s}=f^{I}(\text { educ, entry_cohort })+\sum_{k=1}^{t^{a}} \lambda^{I}{ }_{k}+\sum_{s=t^{a}}^{t} \delta^{I}{ }_{k}+\mu_{t}+\varepsilon_{i t}(2)
\end{aligned}
$$

Earnings assimilation is the process by which two individuals with the same years of labour market experience in their lives differ in their wage growth, in such a way the one with the initial lowest wage approaches the one with the highest. Mathematically, assuming that immigrants have the lowest wage we would require that:

$$
\delta^{I}{ }_{t+1}-\delta^{I}{ }_{t}>\delta^{n}{ }_{t+1}-\delta^{n}{ }_{t}
$$

Let's define an indicator of migrant status I. Pooling (1) and (2), we can specify a model for the pool of workers in this economy as:

$$
\ln W_{i t}=\ln W^{N}{ }_{0}+\sum_{k=1}^{t} \delta^{N}{ }_{k}+\left(\ln W_{0}^{I}-\ln W^{N}{ }_{0}\right) I+\sum_{k=1}^{t^{a}}\left(\lambda^{I}{ }_{k}-\delta^{N}{ }_{k}\right) I_{i}+\sum_{s=t^{a}}^{t}\left(\delta^{I}{ }_{k}-\delta^{N}{ }_{k}\right) I_{i}+\mu_{t}+\varepsilon_{i t}
$$

As it has been suggested in the literature there are some problems associated to the estimation of equation (3) using a single cross-section. In this type of databases, migrants with different years of labour market experience have entered in Spain at different points in time. Therefore, it is impossible to distinguish the wage growth associated with labour market experience from that wage growth associated with changes in the entry cohort quality. Provided, for instance, that there was a decrease in the quality of migrants that enter the 
country over time, as it happened in the United States [Borjas (1999)], the wage growth over the life cycle in the cross section is an upward biased measure of the actual average wage growth. On the other hand, if there was an improvement in the quality of immigrants, the actual wage growth would be underestimated. This problem has been traditionally solved by using several cross sections allowing us to follow the history of different individuals belonging to the same entry cohort.

Even in the case that the quality of migrants was the same over year of entry, we might face an additional estimation problem derived from selective emigration. Let's assume that migrants who decide to go back home after a while are those who perform the worse. In that case the actual wage growth would also be over-estimated in the cross section because those who present higher levels of experience are the best migrants of their cohort of entry. The opposite is true if those migrants who go back home have performed better. This shortcoming cannot be solved by using repeated cross sections.

In order to see both problems mathematically, assume that wage growth for natives and immigrants is constant over time and immigrants arrive in Spain without any experience from abroad:

$$
\begin{array}{ll}
\delta_{k}^{I}=\delta^{I} & \forall k \\
\delta^{N}{ }_{k}=\delta^{N} & \forall k
\end{array}
$$

Notice that the way migrants assimilate with respect to natives is fully estimated by comparing two immigrants with the same characteristics $(X)$ except for the years since migration:

$$
E\left[\ln W_{i, t} \mid X, \text { years_since_mig }=y s m\right]-E\left[\ln W_{i, t} \mid X, \text { years_since_mig }=0\right]=y \operatorname{sm}\left(\delta^{I}-\delta^{N}\right)
$$

In a 2005 cross section, we might for example measure the degree of assimilation after five years of residence in Spain. In that case, we can only compare wages of recent migrants and migrants who arrived five years in advance:

$E\left[\ln W_{i, 2005} \mid\right.$ entry $=2000$, stayer 5 years $]=\ln W^{0}{ }_{i}($ entry $=2005$, stayer 5 years $)+5\left(\delta^{I}-\delta^{N}\right) I_{i}$ $E\left[\ln W_{i, 2005} \mid\right.$ entry $=2005$, just arrived $]=\ln W^{0}{ }_{i}($ entry $=2000$, just arrived $)$

With a single cross section we are not able to distinguish the part of the increase in earnings due to acquisition of experience and human capital as time goes on $5\left(\delta^{I}-\delta^{N}\right)$ - the true measure of assimilation -, and the part due to differences in quality of the different entry cohorts. Decreasing the quality of the cohort of entry biases upward the assimilation profile and vice versa. This possible bias in measuring the size of assimilation on earnings using a single cross section is exacerbated under the presence of selective emigration. Indeed, not all migrants from a particular entry cohort remain in the country for five years. Some might have been unable to pursue their plans, or some might have entered with the idea of a temporary migration. Again, if better immigrants stay longer, assimilation is overestimated. 
Using repeated cross sections we solve the first problem but not the second one since we compare the same entry cohort at different moments of time ${ }^{12}$ :

$$
\begin{aligned}
& E\left[\ln W_{i, 2005} \mid \text { entry }=2000, \text { stayer } 5 \text { years }\right]=\ln W^{0}{ }_{i}(\text { entry }=2000, \text { stayer } 5 \text { years })+5\left(\delta^{I}-\delta^{N}\right) I_{i} \\
& E\left[\ln W_{i, 2000} \mid \text { entry }=2000, \text { just arrived }\right]=\ln W^{0}{ }_{i}(\text { entry }=2000, \text { just arrived })
\end{aligned}
$$

However, using longitudinal data, we observe information on wages in a retrospective way for every individual who enter in a particular year and have stayed in the country until 2005, what allows overcoming both problems:

$$
\begin{aligned}
& E\left[\ln W_{i, 2005} \mid \text { entry }=2000 \text { stayer } 5 \text { years }\right]=\ln W^{0}{ }_{i}(\text { entry }=2000, \text { stayer } 5 \text { years })+5\left(\delta^{I}-\delta^{N}\right) I_{i} \\
& E\left[\ln W_{i, 2000} \mid \text { entry }=2000, \text { stayer } 5 \text { years }\right]=\ln W^{0}{ }_{i}(\text { entry }=2000, \text { stayer } 5 \text { years })
\end{aligned}
$$

Of course, if both the initial wage level and the wage growth once in the country is different for individuals who succeed and individuals who failed, the panel cannot solve completely the problem. In that case, longitudinal data only identifies the assimilation profile of stayers. In next sections we analyze the assimilation profile of different entry cohorts. Recent entry cohorts did not have much time to be selected, whereas previous entry cohorts should be much more selected. If we do not observe many differences in the assimilation profile between the different entry cohorts, we should be more prone to accept the assumption that assimilation is similar for stayers and temporary workers.

In any case, longitudinal data is not absent of problems since it is impossible to discriminate between experience, birth cohort and time effects [Deaton and Paxson (1994)]. In the case of United States, Lubotsky (2007) added a time dummy without considering variations in the cohort effects of natives. In the case of Spain this could generate important shortcomings since there has been an important upgrade in real salaries over Spanish entry cohorts in our data set, due, mainly, to the observed increase in the average educational attainment. There are several ways of identifying cohort effects from time dummies [see Deaton and Paxson (1994) or Kapteyn et al. (2003)]. We follow the strategy of Beaudry and Lemieux (1999) identifying time effects with the structural unemployment rate, or NAIRU, and birth cohorts with different dummies for the age of entry. The NAIRU is computed using a BP filter on the original unemployment series.

12. We are assuming there are not time effects. 
Let's start by showing some raw data that will be helpful in order to understand the ingredients of our wage regression. Figure 1 shows median real earnings per day for native males. Analyzing the initial wage per cohort of entry, there has been a certain upgrade in real earnings over entry cohorts for nationals.

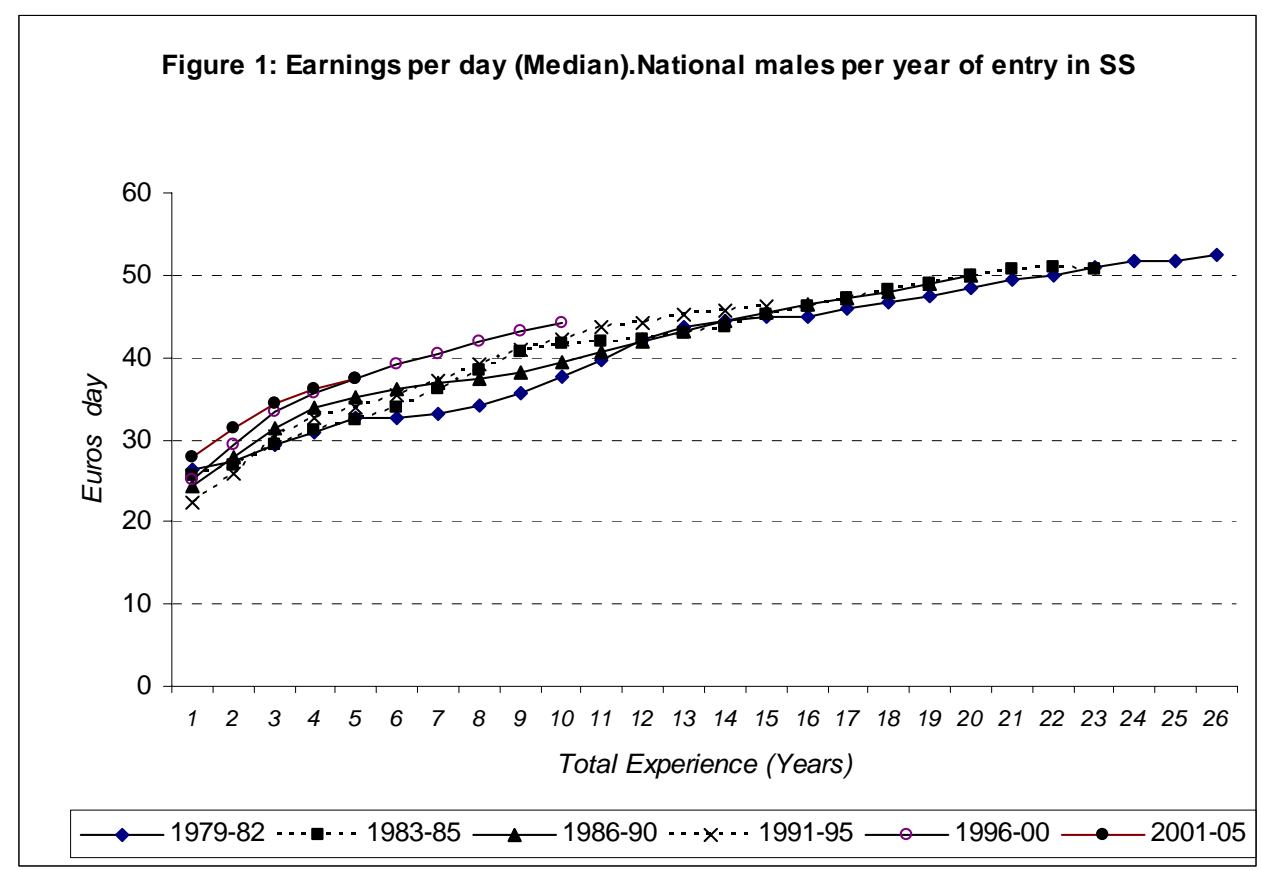

Part of this increase could be attributed to the educational upgrading in the labour force over the last decades. Indeed, those individuals who enter the labour market in 2001-2005 are more educated than those entering in 1978-1982. Moreover, it is possible that the quality of education has also changed over time. That is the reason why we add dummies according to the date of birth in the wage regressions.

Regarding immigrants, figure 2 shows the daily wage experience profile for non EU-15 migrants. The initial level is slightly lower than that of natives, especially for early entry cohorts. However, in this figure, it is much more clear the increase in initial wages per cohort of entry. This upgrading might be picking up an increasing demand for unskilled labour, however, if this was the case, figure 1 would also suffer the same movement at least for very young workers, and this is not the case. Therefore, there should be a notable upgrading of the quality of migrant cohorts. Indeed, in the recent years there has been a shift in the country of origin flows of non-EU-15 migrants, increasing the amount of foreigners coming from South America and the countries of the European enlargement as opposed to Africans. Those first two groups used to have higher educational levels which generate higher wages. We will come back to this issue in section 6.

According to this figure, the experience earnings profile of immigrants is flatter than the one for natives especially for those cohorts entering in recent years. However, this does 
not mean that over time in Spain the wage gap between migrants and non-migrants increases. Indeed, total experience is the sum of experience abroad and after arrival, and the experience earnings profile is a combination of the valuation for both types of experience. For migrants who enter in the recent years, the slope of the curve is almost flat meaning that the experience abroad is less valued in Spain. Instead, the slope becomes steeper for those migrants who have been in Spain for a certain number of years.



This could be also observed in figure 3, where we plot the evolution of daily earning for migrants as experience in Spain increases. Notice that the slope of recent cohorts become steeper while the slope for older cohorts remains more or less unchanged. The abovementioned preliminary evidence makes clear the importance of controlling the experience before migration and the cohort of entry for migrants. 


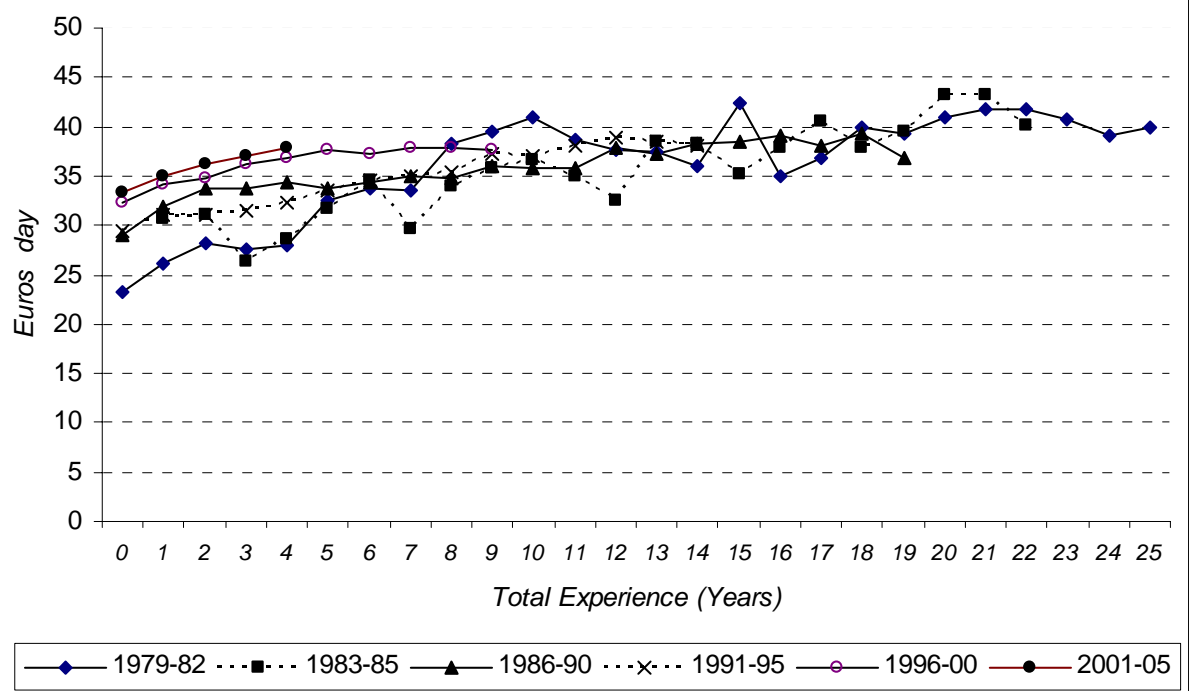

Therefore, if the upgrading of migrants by cohort of entry is confirmed, the results for the assimilation profile in the single cross section will be downward biased because of the increase in quality by migrant cohort. In this case we will need to use the longitudinal data set to solve the problem. So, we estimate equation (3) using the cross section and the longitudinal dataset in order to compare the results. Since the observed value of earnings is top-coded and the censored part is around $15 \%-20 \%$ in the whole sampling period we will use median regressions for the dependent variable, being $\overline{\ln W_{i t}}$ the salary cap ${ }^{13}$ :

$$
\ln W_{i t}^{*}=\min \left(\ln W_{i t}, \overline{\ln W_{i t}}\right)
$$

As in Lubotsky (2007) we use Powell (1984) semi-parametric censored least absolute deviation. We compute the standard deviation with a sandwich estimator [Koenker and Basset (1978)].

In table 2 we show the results for the regression pooling natives and immigrants coming from countries outside the EU-15. In the first three columns of that table the analysis is done with daily wages measured as the ratio between monthly earnings and the days worked in a particular month. The following three columns show the same results using annual wages and the days worked in a particular year. Results are quite similar according to both definitions of daily earnings. The first column of each block shows the wage model estimated using only the information in 2005, as it would be in a cross section. The coefficients in front of the dummies of years since migration express the way the wage gap decreasing over time in Spain. The results do show some assimilation over the time of residence (the first 8 years of experience in Spain reduced the wage differential by 17\%). On the contrary, after that date, assimilation decreases notably.

13. There is also a lower bound for wages (minimum wage). The lower bound is a different problem than the upper bound since the minimum wage coincides with real earnings, whereas the upper bound is different to the real earnings of those in that group. On the other hand, even if we do not believe that minimum wages reflect their productivity, the median regression should not be affected by it. 
However, these results are affected by both changes in the quality of the cohort of entry and selective emigration. Indeed, if there is an increase in the quality of immigrants in the recent years, as it was suggested by the previous figures, the conclusions of assimilation are downward biased. That is the reason why we need to use longitudinal data to estimate equation (3). The advantage of using the panel is that it allows the introduction of quality of entry cohort for migrants and birth cohort for natives. The second column of each block shows the corresponding results. Indeed, the importance of introducing these two variables is clear since in both cases there has been an upgrading of quality. Once we control for this fact, the results regarding assimilation change in a relevant way with respect to what was observed in the cross section. The coefficient in front of the dummy regarding the first two years of experience in Spain indicates that the initial wage gap decreases $8 \mathrm{pp}$ after the first two years. The following two years the wage gap decreases $4 \mathrm{pp}$ additionally (reducing the wage gap in $12 \mathrm{pp}$ ). Finally, those who have stayed in Spain for longer than 8 years present a reduction in the initial wage gap of 20 pp. From that moment on, it does not appear to be further reductions. Differences with the cross-sectional estimation are clearer when we compare results for longer experience. From more than 10 years of experience in Spain, assimilation profile is lower in cross-section estimates. In the next section, we provide evidence on the fact that this is reflecting the observed increase in the quality of more recent migrant's cohorts.

The third column of each block presents the same type of regression excluding those years of the regularization since we know that for those years experience in Spain is not well proxied by the labour experience by the moment of first register in the Social Security. For the other years we are more favoured to match both concepts. Results in terms of assimilation are similar to those in column 2 and 4 . Notice however, that experience abroad, as expected, is less valued in Spain than in the previous estimations. 
Table 2. Wage equation estimations at percentile 50. Dependent variable: logarithm of daily wages*

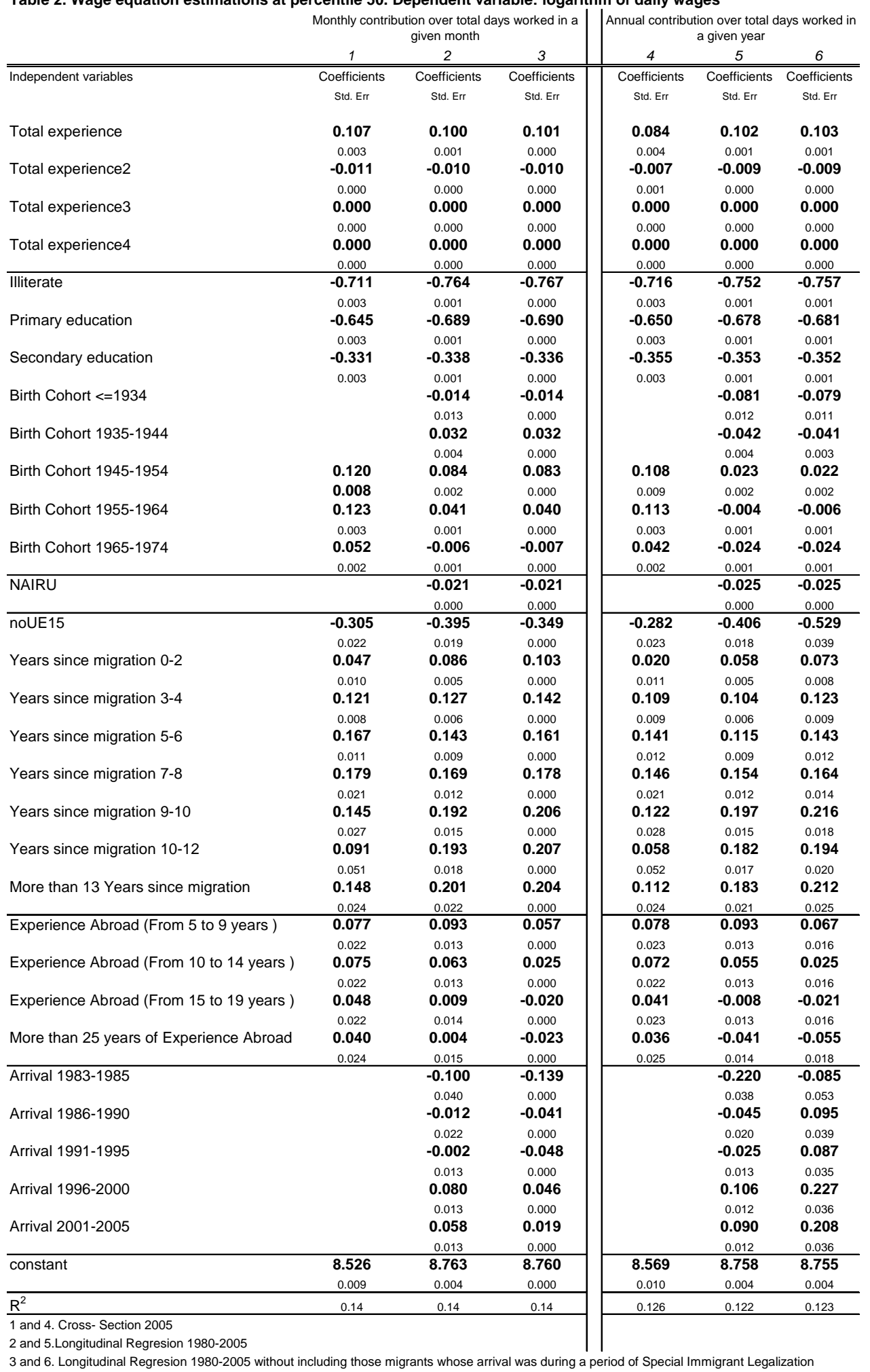


In order to plot the initial wage gap between natives and immigrants and the way it closes over time, we need to compute the wage level for a particular native and a particular immigrant. It is clear from the coefficients of the regression that natives increase their real wages for a given experience and educational attainment the later they are born. In a similar fashion, immigrants increase the wage with the cohort of entry and with a lower level of experience abroad given a level of total experience. Figure 4 plots the wage differential of a native born between 1964 and 1975 and an immigrant who enter Spain between 1995 and 2000 with less than 5 years of experience abroad.

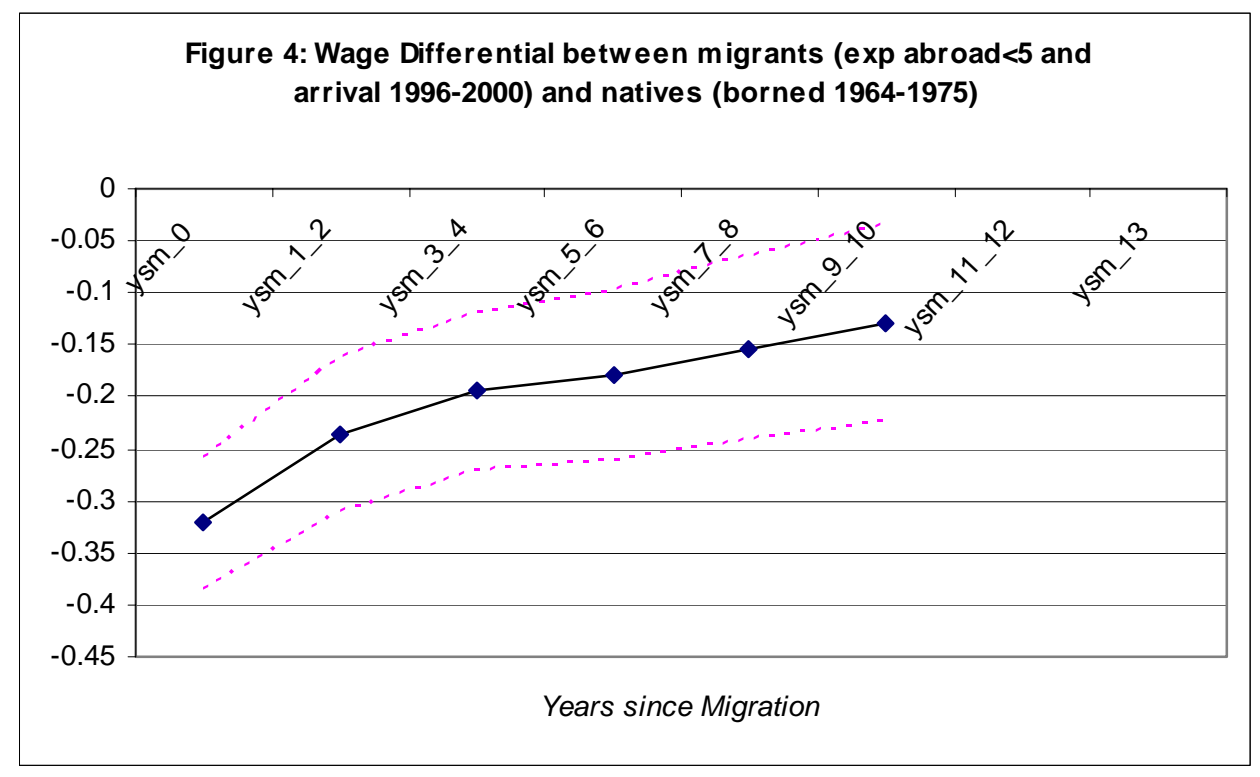

The estimation procedure in section 3 assumed that the wage differences between immigrants of different entry cohorts could be modelled as differences in terms of wage levels instead of assimilation profiles. Figure 5 shows that all cohorts of entry present a similar assimilation pattern. This evidence suggests that assimilation is not importantly affected by a change in the quality of immigrants cohort of entry or selective emigration. Figure 5 also provides an additional robustness check to our results. As we mentioned previously, our definition of a migrant in terms of his nationality in 2005 could be misleading if there is a significant part of migrants who acquired the Spanish nationality once they spend some years in the country, However, as we observe in this figure, given that the assimilation profile is very similar in the more recent cohorts, where migrants have not spent enough time in Spain to get the nationality, we are quite confident that this potential shortcoming is not affecting our main results. Additionally, it should be emphasized that our estimates for the assimilation profile are quite imprecise for the older cohorts, since the relevance of immigration in Spain was very low, but for the more recent years, where the immigration phenomena has taken relevance, we are able to estimate, very precisely, an assimilation process that reduces quite rapidly the initial wage gap for migrants between 10 and $15 \mathrm{pp}$. in the first 5-6 years of experience in the Spanish labour market. 
Figure 5: Assimilation pattern by cohort of entry entry
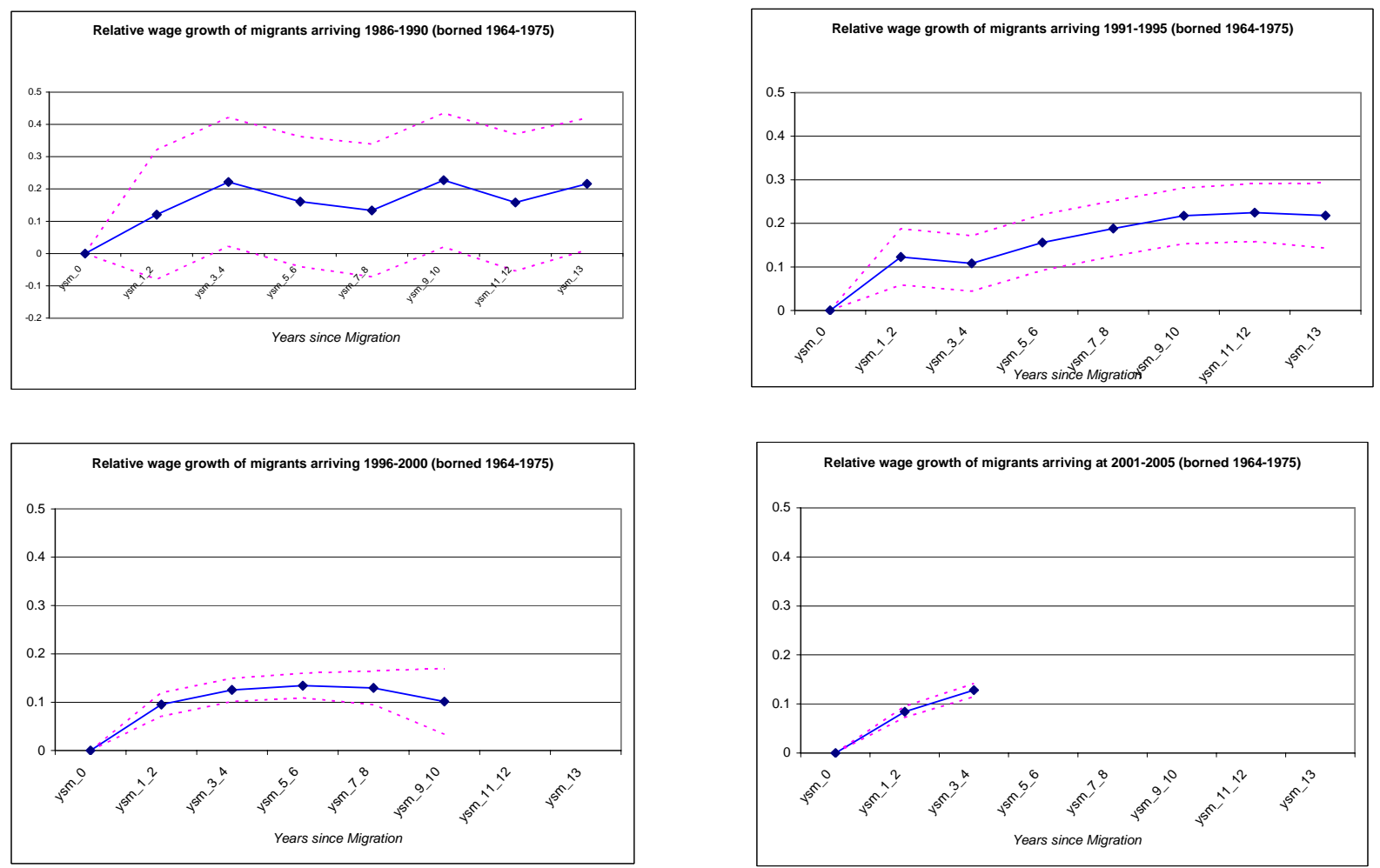


\section{Change in the quality of immigrants over the cohort of entry and selective emigration}

Previous section has shown that the quality of immigrants has increased in the more recent cohorts. The question is whether this change in the quality of immigrants could be attributed to either particular observed characteristic of the new entrants (an improvement in the quality of those who enter Spain for the first time) or it is can be just attributed to the existence of positive selective emigration (those who come back home earlier present a higher quality than the average immigrant) or both. This distinction in relevant since, repeated cross sections might be a proper alternative to analyze assimilation provided that there is no role of selective emigration.

Immigration in Spain has changed enormously in the recent past and this is reflected in our dataset. Table 3 shows the way the composition of total immigration from outside the EU-15 has changed in our sample. In the 80's and the beginning of the 90's, the relative weight of immigrants coming from Africa attained a percentage around $50 \%$. However, over time the weight of migrants coming from Latin-America countries and from countries of the latter European Enlargement has increased a lot.

Both Latin-Americans and immigrants coming from the enlargement have some particularities that make their migrants more likely to have productivity above the average of immigrants from outside the EU-15. Migrants coming from Latin-America countries know the Spanish language, something that is very valuable to find jobs and interact with other co-workers. On the other hand, migrants coming from the enlargement possess higher levels of education relative to other nationalities and although they usually cannot achieve a job that requires all the potential skills they have, they face a much smaller wage gap than other migrants from alternative countries of origin. Indeed, when we break the educational level of immigrants by the year of entry, it is evident that recent migrants present a much higher educational level than those who arrived earlier ${ }^{14}$.

Table 3: Stock of foreign workers in 2005 by year of entry in the Social Security

Enlargement Africa Latinamerican Other

\begin{tabular}{ccccc}
$1983-1985$ & - & $40.51 \%$ & $15.68 \%$ & $43.81 \%$ \\
$1986-1990$ & $3.79 \%$ & $48.81 \%$ & $13.97 \%$ & $33.43 \%$ \\
$1991-1995$ & $5.85 \%$ & $71.50 \%$ & $7.98 \%$ & $14.67 \%$ \\
$1996-2000$ & $9.41 \%$ & $59.70 \%$ & $18.45 \%$ & $12.44 \%$ \\
$2001-2005$ & $20.48 \%$ & $31.98 \%$ & $39.27 \%$ & $8.27 \%$ \\
\hline
\end{tabular}

In order to analyze whether these figures represent changes in the composition of entries or selective emigration we use information from the Municipal Register of Inhabitants (Padrón Municipal de Habitantes). For immigrants, regardless their legal situation in Spain, the register in the Padron provides access to some basic public services for all migrants,

14. This is not only an effect of the compositional change of immigration but it also occurs given a particular country of origin. 
in particular, education and public health care. Therefore, it is expected that even illegal migrants who enter the country will be soon incorporated in these figures. We show the official numbers of entries in Spain broken by nationality in table 4.

Table 4: Inflows of foreigners by year of registration (padrón)

\begin{tabular}{lcccc}
\hline & Enlargement & Africa & Latinamerican & Other \\
\hline & & & & \\
& & & & \\
$1986-1990$ & $6.67 \%$ & $23.69 \%$ & $55.77 \%$ & $13.87 \%$ \\
$1991-1995$ & $5.51 \%$ & $38.89 \%$ & $43.48 \%$ & $12.12 \%$ \\
$1996-2000$ & $9.51 \%$ & $33.76 \%$ & $49.21 \%$ & $7.52 \%$ \\
$2001-2005$ & $24.68 \%$ & $19.00 \%$ & $51.57 \%$ & $4.75 \%$ \\
\hline
\end{tabular}

Average of yearly percentages over the period

It is evident that, in the beginning of the 90's, the percentage of immigrants coming from African countries increased, while Latin-Americans decreased and the other origin countries kept the same numbers. In the second half of the 90's, Latin-Americans and foreigners coming from countries of the Enlargement started increasing its importance. From the 2000 onwards the entries of the enlargement take over. This image on the evolution of entries resembles the variations on the stock that were observed in table 3.

Let us analyze now whether migrants exits to other countries might also contribute to explain part of the pattern in table 3 . It is certainly difficult finding information regarding selective emigration. However, we could use the information available since the introduction of the obligation to renewal of the register every 2 years to immigrants coming from non EU-15 countries and having a non-permanent permit to work in Spain. This renewal was made compulsory since the introduction of a Law in November 2003 and thus was first executed at the end of 2005. At that moment all non-communitarian migrants who enter before the $31^{\text {st }}$ of December had to renew their registers. All potential migrants where informed by mail and it was found that around 500.000 did not renew the register ${ }^{15}$. The Spanish National Institute of Statistics (INE) provided us the dataset with some characteristics of those definite and pending no-renovations in terms of nationality and the year of entry. We could attribute definite no-renovations as individuals who emigrated back home or to another country, and some pending no-renovations will also fit in that category ${ }^{16}$. For a given year of entry, the comparison of the number of no-renovations and the number of entries gives a proxy for an exit rate. This exit rate or emigration rate has only a meaning for the entries of 2003, because the initial register for people who change residency among provinces is replaced by the last movement. Thus, we infer that for those who enter in 2003 there is no much time to move to another province.

Table 5 shows the emigration rates for particular nationalities. This emigration rate is around $18 \%{ }^{17}$. It is found that emigration rates do differ for different countries of origin. The

15. Despite the fact that Municipalities worked hard to find whether individuals left the country or just forgot to renew, since part of their public budget depends on the number of residents. In November 2006, around 260.000 were definitely lost and 280.000 were still being pending.

16. As suggested by INE we impute a rate of no renovations of $50 \%$ for those registers still pending, but this fact does not affect the qualitative results.

17. In the case that all pending registers were found in Spain the rate would be $9 \%$ and it would be $22 \%$ if all pending registers were found to be lost. 
higher rate is for immigrants coming from the enlargement (17\%). Africans and Asian immigrants have very similar emigration rates (16\%) and Latin-Americans appear to be the group with the lowest emigration rates. Older males in all nationalities appear to be more likely to emigrate back home.

Table 5: No renewals of the register in 2005 for those who entered in 2003 Romania and Africa America Total

Emigration rate $\quad 22.33 \% \quad 20.57 \% \quad 16.06 \% \quad 18.41 \%$

This evidence would reinforce the idea that better immigrants in terms of education are the ones with higher probabilities of exit. Indeed, as it is shown in figure 6, other nationalities such as the United States, Chile or Argentina with high educational attainment and despite their distance from Spain presenting also higher exit rates. Therefore, this evidence suggests that positive selective emigration also contributed to the change in the quality of immigrants by cohort of entry, increasing the doubts on using repeated cross-sections to analyze this particular question for the Spanish case.

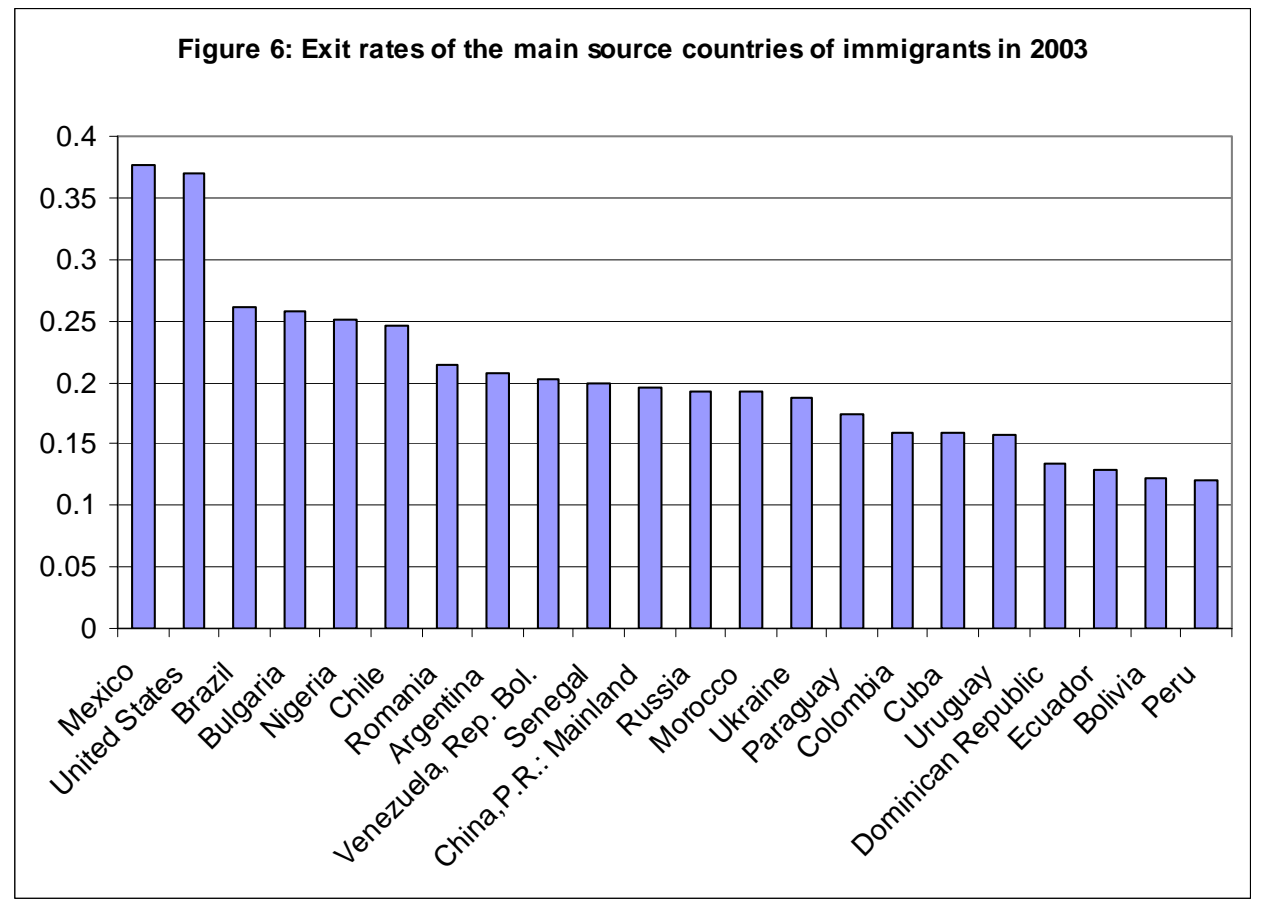




\section{Mechanisms underlying assimilation}

In the previous sections we showed that the immigrant wage gap reduces with the time spent in Spain since the pace of growth of immigrant wages is faster than the one corresponding to their native counterparts, and therefore the existing arrival wage gap reduces notably after the first seven-eight years in Spain, although not disappearing completely.

The next step should be to understand the mechanisms underlying this wage assimilation process. In the introduction we proposed two possible explanations for this different wage growth pace. On the one hand, more occupationally mobile and dynamic workers should be prone to improve their wages, because they move to those places where they are better paid. Notice that immigrants are more mobile than natives because they are less attached to a particular region than Spaniards. Other plausible reason that may be behind the observed wage convergence could be the conventional human capital accumulation once in the destination country. As time goes on, they adapt their knowledge and qualifications to the host country and acquire new skills and abilities that make them more prone to benefit from their previous skills ore even more productive in absolute terms and as a consequence better paid.

In order to asses whether the catching up to the native born earnings levels could be explained as a result of the higher degree of migrants' mobility, we consider changes in the province. Notice that most temporary work permits restrict the movement of province and sector during the first years, but once it is renewed, the immigrant might move freely. Human capital gains might be reflected in changes outside the initial firm (changing sector within the province or changing firm within the province and sector), or within the initial firm.

In a sense, we are going to take equation (3) and taking first differences we define changes in the log wage as in equation (4):

$$
\begin{aligned}
& \Delta \ln W_{i t+1}=\delta^{N}{ }_{t+1}+\left(\delta^{I}{ }_{t+1}-\delta^{N}{ }_{t+1}\right) I_{i}+v_{i t+1}= \\
& =\delta^{N}{ }_{t+1}+\lambda_{0} I_{i}+\lambda_{1} \text { prov_mov }+\lambda_{2} \text { sector_mov }+\lambda_{3} \text { company_mov }+u_{i t}
\end{aligned}
$$

Hence, all fixed effects vanish and the wage growth differential between natives and immigrants $\left(\delta^{I}{ }_{t+1}-\delta^{N}{ }_{t+1}\right)$ will be explained by different propensity to regional mobility $\lambda_{1}$, human capital accumulation that exacerbate a change of sector $\lambda_{2}$ or firm $\lambda_{3}$ and human capital accumulation that yields a payoff within the initial firm $\lambda_{0}$.

Doing this analysis with our data set requires defining the labour status of the worker in a bunch of categories: province, sector of activity and working company. Since it provides information about all the "legal" labour relations that the workers have every day, it is difficult to assign a single value to every dimension, because they might be working simultaneously in two or more jobs with different characteristics. As a strategy we follow the 
same steps as INE that were mentioned in section $4^{18}$. By doing this, we get a labour sequence of all labour dimensions mentioned before for each individual in the sample and, it is possible to compute the probability of changes from one year to other for each specific dimension considered. It is also important to remark that we restrict the analysis to only those labour relations that are under General Regime.

Table 6 provides the probit coefficients for the regression of changes in labour status from one year to another. This table shows that no UE 15 workers in Spain are more occupationally mobile than natives in the three dimensions above mentioned. This higher mobility starts being relevant after the first two years, when legal restrictions are overcome and decreases over time.

Table 6: Yearly change of status

Depend Variable

\begin{tabular}{|c|c|c|c|}
\hline & $\begin{array}{c}\text { Province } \\
\text { (1) }\end{array}$ & $\begin{array}{l}\text { Sector } \\
\text { (2) }\end{array}$ & $\begin{array}{c}\text { Company } \\
\text { (3) } \\
\end{array}$ \\
\hline \multirow[t]{2}{*}{ noUE-15 } & 0.008 & -0.006 & -0.021 \\
\hline & 0.001 & 0.001 & 0.002 \\
\hline \multirow[t]{2}{*}{ Years since migration 3-4 } & 0.026 & 0.055 & 0.014 \\
\hline & 0.001 & 0.002 & 0.003 \\
\hline \multirow[t]{2}{*}{ Years since migration 5-6 } & 0.011 & 0.029 & 0.092 \\
\hline & 0.001 & 0.003 & 0.005 \\
\hline \multirow[t]{2}{*}{ Years since migration 7-8 } & 0.000 & 0.019 & 0.063 \\
\hline & 0.002 & 0.004 & 0.006 \\
\hline \multirow[t]{2}{*}{ Years since migration 9-10 } & 0.001 & 0.023 & 0.074 \\
\hline & 0.003 & 0.005 & 0.008 \\
\hline \multirow[t]{2}{*}{ Years since migration 10-12 } & 0.002 & 0.007 & 0.023 \\
\hline & 0.003 & 0.006 & 0.009 \\
\hline \multirow[t]{2}{*}{ More than 13 Years since migration } & -0.006 & 0.004 & 0.021 \\
\hline & 0.000 & 0.006 & 0.000 \\
\hline \multirow[t]{2}{*}{ Age } & 0.000 & -0.001 & 0.001 \\
\hline & 0.000 & 0.000 & 0.000 \\
\hline \multirow[t]{2}{*}{ Iliterate } & 0.003 & -0.002 & 0.016 \\
\hline & 0.000 & 0.001 & 0.001 \\
\hline \multirow[t]{2}{*}{ Primary } & 0.003 & 0.002 & 0.016 \\
\hline & 0.000 & 0.001 & 0.001 \\
\hline \multirow[t]{2}{*}{ Secondary } & 0.002 & -0.003 & -0.006 \\
\hline & 0.000 & 0.001 & 0.001 \\
\hline \multirow[t]{2}{*}{ Constant } & 0.001 & 0.080 & 0.111 \\
\hline & 0.000 & 0.001 & 0.001 \\
\hline
\end{tabular}

\footnotetext{
18. We restrict the period of interest to a specific quarter of the year: we choose the second quarter. It makes easier the comparison with other data sources as LFS. Each individual is randomly assigned to a reference week during the second quarter of the year (as it happens with the interviews of the LFS). After that, we define her labour situation during that quarter depending on what she is doing during her reference week. If the individual has more than one job during the reference week, we choose among all of them the permanent one. If several are permanent (or all are temporal), we choose the longer during the month corresponding to the reference week in the quarter. If several are permanent (or all are temporal) and have the same length during the month, we choose the one that begins earlier. If still those conditions are the same, we choose the one that finishes later. We repeat the process for all the working years.
} 
To inspect the influence of the labour choices - changes in province, sector, firm and type of contract within the company - on the increase of wages, we will perform OLS regression of the increase in the logarithm of wages of the non top coded observations. Results are shown in Table 7. The first column identifies that immigrants from outside the EU15 experienced a wage growth that is $1.8 \mathrm{pp}$ higher than comparable natives. The coefficient in front of the variable years since migration identifies the fact that this differential higher wage growth for immigrants vanishes over time and eventually disappears in 9 years. This result is consistent with what was obtained in section 5. Column 2 controls for interprovincial movements. Controlling for those movements, only explains $2 \mathrm{pp}$ of the differential wage growth since the coefficient in front of the immigrant dummy decreases from 1.8 to $1.6 \mathrm{pp}$.. This means that the different inter-regional mobility of migrants and natives is only responsible of $11 \%$ of the assimilation profile. Consequently, almost $90 \%$ of the differential wage growth should be found within the same province either by changes across sectors, firms or within the same company ${ }^{19}$.

Table 7: Ols regressions of the yearly log wage change of non top coded individuals

\begin{tabular}{lcccc}
\hline \multicolumn{1}{c}{ Independent variables } & $(\mathbf{1})$ & $(\mathbf{2})$ & $\mathbf{( 3 )}$ & $(\mathbf{4})$ \\
\hline \multirow{2}{*}{ noUE15 } & 0.018 & 0.016 & 0.012 & 0.009 \\
& $(0,003)$ & $(0,003)$ & $(0,003)$ & $(0,003)$ \\
Years since migration & -0.002 & -0.002 & -0.002 & -0.002 \\
& $(0,000)$ & $(0,000)$ & $(0,000)$ & $(0,000)$ \\
Total experience & -0.023 & -0.023 & -0.023 & -0.022 \\
& $(0,000)$ & $(0,000)$ & $(0,000)$ & $(0,000)$ \\
Total experience2 & 0.001 & 0.001 & 0.001 & 0.001 \\
& $(0,000)$ & $(0,000)$ & $(0,000)$ & $(0,000)$ \\
Total experience3 & 0.000 & 0.000 & 0.000 & 0.000 \\
& $(5.49 \mathrm{e}-07)$ & $(5.49 \mathrm{e}-07)$ & $(5.49 \mathrm{e}-07)$ & $(5.49 \mathrm{e}-07)$ \\
Change in province & & 0.036 & 0.039 & 0.042 \\
& & $(0,002)$ & $(0,002)$ & $(0,002)$ \\
Change sector within province & & & 0.058 & 0.061 \\
& & & $(0,001)$ & $(0,001)$ \\
Change firm within sector and province & & & & 0.037 \\
& & & & $(0,001)$ \\
Year dummies & Yes & Yes & Yes & Yes \\
Constant & & & & 0.123 \\
& 0.129 & 0.129 & 0.125 & $(0,006)$ \\
\hline
\end{tabular}

Finally, in column 4, all those abovementioned changes are controlled and we conclude that $50 \%$ of the differential wage growth occurs within the firm. Wrapping up the abovementioned numbers, higher mobility of migrants across regions is responsible for $10 \%$ of the wage growth differential, changes in sector and corporations within the same province are responsible for $40 \%$ of the wage growth differential, and the rest is attributed to a better behaviour of immigrants respect to natives within the same initial firm. We interpret this result as evidence that most of the assimilation of immigrants comes from human capital gains that materialize in similar proportions by an improvement in his labour situation within the initial firm or by moving out from low-paid sectors and corporations to better ones.

19. It is also possible that migrants were more mobile across municipalities than natives, but this is an issue that we cannot test with this dataset. 
In this paper we have analyzed earnings assimilation of immigrants in Spain using longitudinal data. Immigration in Spain has become a matter of very high relevance in the recent years since the percentage of immigrants in the Spanish population increased from $2 \%$ in 2000 to $11 \%$ six years later. We used a novel dataset of labour market histories to analyze how relative earnings of male immigrants to Spain evolve over time with respect to Spanish born workers. We show that the initial wage differential with respect to natives with the same observable characteristics decreases with time spent in Spain. According to our estimates, assimilation of legal immigrants is pretty rapid, with a reduction of around the half of the initial wage gap during the first 5-6 years. However, we do not observe that the wage gap vanishes completely. Overall, these results are quite robust to different data assumptions and, in particular, the assimilation process we estimate is quite similar across different immigrant's entry cohorts.

The approach on this paper is a step forward respect to previous studies of earnings assimilation using single or repeated cross sections because it takes into account the fact that in Spain an important change in the quality of immigrants has taken place. Previous studies had underestimated earnings assimilation by not taking into consideration the selection of inflows or outflows. Indeed, the paper shows that Spain has changed the composition of immigrants in terms of their country of origin. In recent years, the relative weight of Latin-Americans and immigrants from the European Enlargement had grown notably respect to Africans. As a consequence, the initial wage gap of the average immigrant has decreased. Moreover, the paper shows that there is some positive selective emigration: countries such as the United States, Argentina, Bulgaria or Romania that have high educational attainment respect to the average immigrant present high exit rates. Both phenomena invalidate using single or repeated cross sections to analyze earnings assimilation in Spain.

There are two hypotheses behind the positive wage growth differential between migrants and natives. On the one hand, the initial low level of human capital, at least that part which is more useful in the destination country, compared to the level faced by comparable natives, justifies a high incentive to invest in human capital upon arrival. On the other, in a regulated labour market such as the Spanish, there are many institutions that exacerbate economic differences across regions or municipalities. Migrants are more prone to benefit from those differences since they have lower social attachments than natives. In order to separate out those two mechanisms we analyze how the wage growth differs between migrants and Spaniards, first unconditionally, and second controlling for movements across provinces. It appears that movements across regions might only explain $11 \%$ of the wage growth differential between migrants and non-migrants. Consequently, most of the assimilation should be attributed to human capital gains. Moreover, human capital gains are mostly materialized within the initial firm instead of being the results of between firm's mobility, either with changes across sectors or companies.

To conclude, our results could be indicating a positive contribution of immigration to the evolution of productivity in the Spanish economy over the coming years. Large immigration flows received in the recent past has, at least partly [see Banco de España (2006) and Lacuesta et al. (2008)], contributed to poor productivity performance. Our paper has 
shown that the initial wage, or productivity, gap between natives and immigrants rapidly decreases as immigrants acquire country-specific human capital. Hence, in the near future, while lower immigrant flows are expected ${ }^{20}$, the assimilation profile of those migrants already in the Spanish labour market will tend to positively contribute to productivity growth. In any case, we should also recognize that much uncertainty remains about the behaviour of immigrants in the Spanish labour market since the immigration phenomena has taken place in a especially positive economic environment.

20. According to the last population projections made by INE, immigration flows will decrease in the coming years to around one half of those observed in the more recent past. 


\section{REFERENCES}

ADSERA, A., and CHISWICK, B. (2007). "Are there gender and country of origin differences in immigrant labour market outcomes across European destinations?", Journal of Population Economics, Springer, Vol. 20 (3), July, pp. 495-526.

AMUEDO-DORANTES, C., and S. DE LA RICA (2007a). "Labour Market Assimilation of Recent Immigrants in Spain". British Journal of Industrial Relations, Vol. 45, No. 2, June, pp. 257-284.

- (2007b). Does Immigration Raise Natives Income? National and Regional Evidence from Spain, IZA Discussion Paper 3486.

ANTECOL, H., P. J. KUHN and S. TREJO (2006). "Assimilation via Prices of Quantities? Labour Market Institutions and Immigrant Earnings Growth in Australia, Canada and the United States”, Journal of Human Resources, Vol. 41 (4), pp. 821-840.

BANCO DE ESPAÑA (2006). "The Growth of the Spanish Economy: Some Basic Determinants", Chapter 2 in the Annual Report 2006, pp. 42-45.

BEAUDRY, P., and T. LEMIEUX (1999). Evolution of the female Labour Force Participation Rate in Canada, 1976-1994, mimeo, Centre Interuniversitaire de Reserche en Analyse des Organisations.

BEN-PORATH, Y. (1967). "The Production of Human Capital and the Life Cycle of Earnings". The Journal of Political Economy, Vol. 75, No. 4, August, pp. 352-365.

BORJAS, G. (1999. Heaven's Door: Immigration Policy and the American Economy, Princeton University Press.

CARRASCO, R., J. F. JIMENO and C. ORTEGA (2008). "The Effect of Immigration on the Employment Opportunities of Native Born Workers: Some Evidence for Spain", Journal of Population Economics, forthcoming.

CHISWICK, B. (1978)."The Effect of Americanization on the Earnings of Foreign-Born Men", Journal of Political Economy, 86 (5), October, pp. 897-922.

DEATON, A., and C. PAXSON (1994). "Intertemporal Choice and Inequality", The Journal of Political Economy, Vol. 102. No. 3, June, pp. 437-467.

FERNÁNDEZ, C., and C. ORTEGA (2006). Labour Market Assimilation of Immigrants in Spain: Employment at the Expense of Bad Job-Matches?, IESE Business School Working Paper No. 644, September.

IZQUIERDO, M., and A. LACUESTA (2005). "Heterogeneidad en los Mercados de Trabajo Regionales", Economic Bulletin, October, Banco de España (Spanish versión).

HU, W.-Y. (2000). "Immigrant Earnings Assimilation: Estimates from Longitudinal Data", The American Economic Review, Vol. 90, No. 2, Papers and Proceedings of the One Hundred Twelfth Annual Meeting of the American Economic Association, pp. 368-372.

KAPTEYN, A., R. ALESSIE and A. LUSARDI (2005). "Explaining the wealth holdings of different cohorts: Productivity growth and Social Security", European Economic Review, 49, pp. 1361-1391

KOENKER, R., and G. BASSET Jr. (1978). "Regression Quantiles", Econometrica, Vol. 36, pp. 33-50.

LACUESTA, A., S. PUENTE and P. CUADRADO (2008). Omitted Variables in the Measure of a Labour Quality Index: The Case of Spain, Working Paper series Banco de España 0835.

LaLONDE, R., and R. TOPEL (1992). "The Assimilation of Immigrants on the US labour market" in "Immigration and the Work Force: Economic Consequences for the United States and Source Areas" edited by Borjas, Georges J. and Freeman, Richard B. The University of Chicago Press Ltd. London. Printed in USA, pp. 63-97.

LUBOTSKY, D. (2007). "Chutes or Ladders? A Longitudinal Analysis of Immigrant Earnings", Journal of Political Economy, Vol. 115, No. 5.

OCDE (2007). Trends in International Migration, 2005 Edition.

POWELL, J. (1984). "Least Absolute Deviations Estimation for the Censored Regression Model", Journal of Econometrics, 25, July, pp. 303-325.

RAMOS-MUÑOZ, B. (2007). "Comparación de las Magnitudes Estadísticas del Empleo según la Encuesta de Población Activa y la Muestra Continua de Vidas Laborales" mimeo presented in Jornadas de Usuarios de la Muestra Continua de Vidas Laborales, FEDEA (Madrid).

SJAASTAD, L. (1962). "The Costs and Returns of Human Migration", Journal of Political Economy, Vol. 70, Issue 5, Part 2, pp. 80-93. 


\section{BANCO DE ESPAÑA PUBLICATIONS}

\section{WORKING PAPERS ${ }^{1}$}

0721 CLAUDIA CANALS, XAVIER GABAIX, JOSEP M. VILARRUBIA AND DAVID WEINSTEIN: Trade patterns, trade balances and idiosyncratic shocks.

0722 MARTÍN VALLCORBA AND JAVIER DELGADO: Determinantes de la morosidad bancaria en una economía dolarizada. El caso uruguayo.

0723 ANTÓN NÁKOV AND ANDREA PESCATORI: Inflation-output gap trade-off with a dominant oil supplier.

0724 JUAN AYUSO, JUAN F. JIMENO AND ERNESTO VILLANUEVA: The effects of the introduction of tax incentives on retirement savings.

0725 DONATO MASCIANDARO, MARÍA J. NIETO AND HENRIETTE PRAST: Financial governance of banking supervision.

0726 LUIS GUTIÉRREZ DE ROZAS: Testing for competition in the Spanish banking industry: The Panzar-Rosse approach revisited.

0727 LUCÍA CUADRO SÁEZ, MARCEL FRATZSCHER AND CHRISTIAN THIMANN: The transmission of emerging market shocks to global equity markets.

0728 AGUSTÍN MARAVALL AND ANA DEL RíO: Temporal aggregation, systematic sampling, and the Hodrick-Prescott filter.

0729 LUIS J. ÁLVAREZ: What do micro price data tell us on the validity of the New Keynesian Phillips Curve?

0730 ALFREDO MARTíN-OLIVER AND VICENTE SALAS-FUMÁS: How do intangible assets create economic value? An application to banks.

0731 REBECA JIMÉNEZ-RODRÍGUEZ: The industrial impact of oil price shocks: Evidence from the industries of six OECD countries.

0732 PILAR CUADRADO, AITOR LACUESTA, JOSÉ MARÍA MARTÍNEZ AND EDUARDO PÉREZ: El futuro de la tasa de actividad española: un enfoque generacional.

0733 PALOMA ACEVEDO, ENRIQUE ALBEROLA AND CARMEN BROTO: Local debt expansion... vulnerability reduction? An assessment for six crises-prone countries.

0734 PEDRO ALBARRÁN, RAQUEL CARRASCO AND MAITE MARTÍNEZ-GRANADO: Inequality for wage earners and self-employed: Evidence from panel data.

0735 ANTÓN NÁKOV AND ANDREA PESCATORI: Oil and the Great Moderation.

0736 MICHIEL VAN LEUVENSTEIJN, JACOB A. BIKKER, ADRIAN VAN RIXTEL AND CHRISTOFFER KOK-SØRENSEN: A new approach to measuring competition in the loan markets of the euro area.

0737 MARIO GARCÍA-FERREIRA AND ERNESTO VILLANUEVA: Employment risk and household formation: Evidence from differences in firing costs.

0738 LAURA HOSPIDO: Modelling heterogeneity and dynamics in the volatility of individual wages.

0739 PALOMA LÓPEZ-GARCÍA, SERGIO PUENTE AND ÁNGEL LUIS GÓMEZ: Firm productivity dynamics in Spain.

0740 ALFREDO MARTÍN-OLIVER AND VICENTE SALAS-FUMÁS: The output and profit contribution of information technology and advertising investments in banks.

0741 ÓSCAR ARCE: Price determinacy under non-Ricardian fiscal strategies.

0801 ENRIQUE BENITO: Size, growth and bank dynamics.

0802 RICARDO GIMENO AND JOSÉ MANUEL MARQUÉS: Uncertainty and the price of risk in a nominal convergence process.

0803 ISABEL ARGIMÓN AND PABLO HERNÁNDEZ DE COS: Los determinantes de los saldos presupuestarios de las Comunidades Autónomas.

0804 OLYMPIA BOVER: Wealth inequality and household structure: US vs. Spain.

0805 JAVIER ANDRÉS, J. DAVID LÓPEZ-SALIDO AND EDWARD NELSON: Money and the natural rate of interest: structural estimates for the United States and the euro area.

0806 CARLOS THOMAS: Search frictions, real rigidities and inflation dynamics.

0807 MAXIMO CAMACHO AND GABRIEL PEREZ-QUIROS: Introducing the EURO-STING: Short Term INdicator of Euro Area Growth.

0808 RUBÉN SEGURA-CAYUELA AND JOSEP M. VILARRUBIA: The effect of foreign service on trade volumes and trade partners.

0809 AITOR ERCE: A structural model of sovereign debt issuance: assessing the role of financial factors.

0810 ALICIA GARCÍA-HERRERO AND JUAN M. RUIZ: Do trade and financial linkages foster business cycle synchronization in a small economy?

1. Previously published Working Papers are listed in the Banco de España publications catalogue. 
0811 RUBÉN SEGURA-CAYUELA AND JOSEP M. VILARRUBIA: Uncertainty and entry into export markets.

0812 CARMEN BROTO AND ESTHER RUIZ: Testing for conditional heteroscedasticity in the components of inflation.

0813 JUAN J. DOLADO, MARCEL JANSEN AND JUAN F. JIMENO: On the job search in a model with heterogeneous jobs and workers.

0814 SAMUEL BENTOLILA, JUAN J. DOLADO AND JUAN F. JIMENO: Does immigration affect the Phillips curve? Some evidence for Spain.

0815 ÓSCAR J. ARCE AND J. DAVID LÓPEZ-SALIDO: Housing bubbles.

0816 GABRIEL JIMÉNEZ, VICENTE SALAS-FUMÁS AND JESÚS SAURINA: Organizational distance and use of collateral for business loans.

0817 CARMEN BROTO, JAVIER DÍAZ-CASSOU AND AITOR ERCE-DOMÍNGUEZ: Measuring and explaining the volatility of capital flows towards emerging countries.

0818 CARLOS THOMAS AND FRANCESCO ZANETTI: Labor market reform and price stability: an application to the Euro Area

0819 DAVID G. MAYES, MARÍA J. NIETO AND LARRY D. WALL: Multiple safety net regulators and agency problems in the EU: Is Prompt Corrective Action partly the solution?

0820 CARMEN MARTÍNEZ-CARRASCAL AND ANNALISA FERRANDO: The impact of financial position on investment: an analysis for non-financial corporations in the euro area.

0821 GABRIEL JIMÉNEZ, JOSÉ A. LÓPEZ AND JESÚS SAURINA: Empirical analysis of corporate credit lines.

0822 RAMÓN MARÍA-DOLORES: Exchange rate pass-through in new Member States and candidate countries of the EU.

0823 IGNACIO HERNANDO, MARÍA J. NIETO AND LARRY D. WALL: Determinants of domestic and cross-border bank acquisitions in the European Union.

0824 JAMES COSTAIN AND ANTÓN NÁKOV: Price adjustments in a general model of state-dependent pricing.

0825 ALFREDO MARTÍN-OLIVER, VICENTE SALAS-FUMÁS AND JESÚS SAURINA: Search cost and price dispersion in vertically related markets: the case of bank loans and deposits.

0826 CARMEN BROTO: Inflation targeting in Latin America: Empirical analysis using GARCH models.

0827 RAMÓN MARÍA-DOLORES AND JESÚS VAZQUEZ: Term structure and the estimated monetary policy rule in the eurozone.

0828 MICHIEL VAN LEUVENSTEIJN, CHRISTOFFER KOK SØRENSEN, JACOB A. BIKKER AND ADRIAN VAN RIXTEL: Impact of bank competition on the interest rate pass-through in the euro area.

0829 CRISTINA BARCELÓ: The impact of alternative imputation methods on the measurement of income and wealth: Evidence from the Spanish survey of household finances.

0830 JAVIER ANDRÉS AND ÓSCAR ARCE: Banking competition, housing prices and macroeconomic stability.

0831 JAMES COSTAIN AND ANTÓN NÁKOV: Dynamics of the price distribution in a general model of state-dependent pricing.

0832 JUAN A. ROJAS: Social Security reform with imperfect substitution between less and more experienced workers.

0833 GABRIEL JIMÉNEZ, STEVEN ONGENA, JOSÉ LUIS PEYDRÓ AND JESÚS SAURINA: Hazardous times for monetary policy: What do twenty-three million bank loans say about the effects of monetary policy on credit risk-taking?

0834 ENRIQUE ALBEROLA AND JOSÉ MARÍA SERENA: Sovereign external assets and the resilience of global imbalances.

0835 AITOR LACUESTA, SERGIO PUENTE AND PILAR CUADRADO: Omitted variables in the measure of a labour quality index: the case of Spain.

0836 CHIARA COLUZZI, ANNALISA FERRANDO AND CARMEN MARTÍNEZ-CARRASCAL: Financing obstacles and growth: An analysis for euro area non-financial corporations.

0837 ÓSCAR ARCE, JOSÉ MANUEL CAMPA AND ÁNGEL GAVILÁN: Asymmetric collateral requirements and output composition.

0838 ÁNGEL GAVILÁN AND JUAN A. ROJAS: Solving Portfolio Problems with the Smolyak-Parameterized Expectations Algorithm.

0901 PRAVEEN KUJAL AND JUAN RUIZ: International trade policy towards monopoly and oligopoly.

0902 CATIA BATISTA, AITOR LACUESTA AND PEDRO VICENTE: Micro evidence of the brain gain hypothesis: The case of Cape Verde.

0903 MARGARITA RUBIO: Fixed and variable-rate mortgages, business cycles and monetary policy.

0904 MARIO IZQUIERDO, AITOR LACUESTA AND RAQUEL VEGAS: Assimilation of immigrants in Spain: A longitudinal analysis.

\begin{tabular}{|r|c|}
\hline & Unidad de Publicaciones \\
BANCODEESPAÑ & Alcalá, 522; 28027 Madrid \\
Eurosistema & Telephone +34 91 338 6363. Fax +34 913386488 \\
& e-mail: publicaciones@bde.es \\
www.bde.es
\end{tabular}

